\title{
Wind waves in the Black Sea: results of a hindcast study
}

\author{
V. S. Arkhipkin, F. N. Gippius, K. P. Koltermann, and G. V. Surkova \\ Moscow State University, Faculty of Geography, Moscow, Russia \\ Correspondence to: F. N. Gippius (fedor.gippius@gmail.com)
}

Received: 16 December 2013 - Published in Nat. Hazards Earth Syst. Sci. Discuss.: 6 February 2014

Revised: 29 August 2014 - Accepted: 6 September 2014 - Published: 5 November 2014

\begin{abstract}
In this study we describe the wind wave fields in the Black Sea. The general aims of the work were the estimation of statistical wave parameters and the assessment of interannual and seasonal wave parameter variability. The domain of this study was the entire Black Sea. Wave parameters were calculated by means of the SWAN wave model on a $5 \times 5 \mathrm{~km}$ rectangular grid. Initial conditions (wind speed and direction) for the period between 1949 and 2010 were derived from the NCEP/NCAR reanalysis. According to our calculations the average significant wave height on the Black Sea does not exceed $0.7 \mathrm{~m}$. Areas of most significant heavy sea are the southwestern and the northeastern parts of the sea as expressed in the spatial distribution of significant wave heights, wave lengths and periods. Besides, long-term annual variations of wave parameters were estimated. Thus, linear trends of the annual total duration of storms and of their quantity are nearly stable over the hindcast period. However, an intensification of storm activity is observed in the 1960s1970s.
\end{abstract}

\section{Introduction}

Any human activity in the off-shore or coastal areas is directly affected by the ocean. To settle, live, work and plan in these areas requires data on the marine climate. As the oceans and their shores are used more and more intensely for a variety of purposes, such as marine transport, offshore mining operations and recreation, these data have to meet more and more exacting requirements. A regular distribution in time and space is a great advantage of any data set, as it makes it more convenient to use for further purposes than randomly scattered in situ data with a short time span.

Nowadays, numerical modelling seems to be the most appropriate method of generating such data sets. The main advantage of this technique is its flexibility relative to the formulation of initial conditions, the calculated parameters and the resolutions - both temporal and spatial. Another advantage of modelling studies is the possibility to perform hindcast and forecast calculations using archived or forecast wind fields. Operational wave forecasting on different spatial scales is a state-of-the-art field in which numerical modelling is used (e.g. Ponce de Léon et al., 2012).

Traditional in situ measurements do not possess these advantages, as they are usually performed during relatively short survey campaigns and/or by means of gauges at locations that do not permit obtaining data over the whole domain of interest. However, such measurements are very important as they are the only way to validate and calibrate the models.

Much attention has been devoted to the study of ocean wave climate and its recent variability. This research is carried out on a variety of both temporal and spatial scales. Thus, a part of the research is dedicated to global wind and waves climate (Peterson and Hasse, 1987; Sterl et al., 1998). However, more or less regional hindcast studies prevail in this field, e.g. studies of the Northern Atlantic Ocean (Kaas et al., 1996), European seas (Soares et al., 2002) and their constituent parts (Soomere, 2005; Dodet et al., 2010; Charles et al., 2012b). Finally, numerous studies have been focused on assessing the mechanisms of changes in wave climate and its relation with atmospheric circulation indices (e.g. Kushnir et al., 1997; Lionello and Sanna, 2005; Charles et al., 2012a).

Storms are the most hazardous manifestation of combined wind and wave action. They may cause severe damage both offshore and on land (Alexander et al., 2005; Matulla et al., 2008). Marine storms are the subject of numerous studies. For example, a statistical assessment of storms off the eastern coast of the USA during a period of more than 40 years is presented by Dolan et al. (1988). Changes in storm activity during recent decades were discussed in detail. However, 

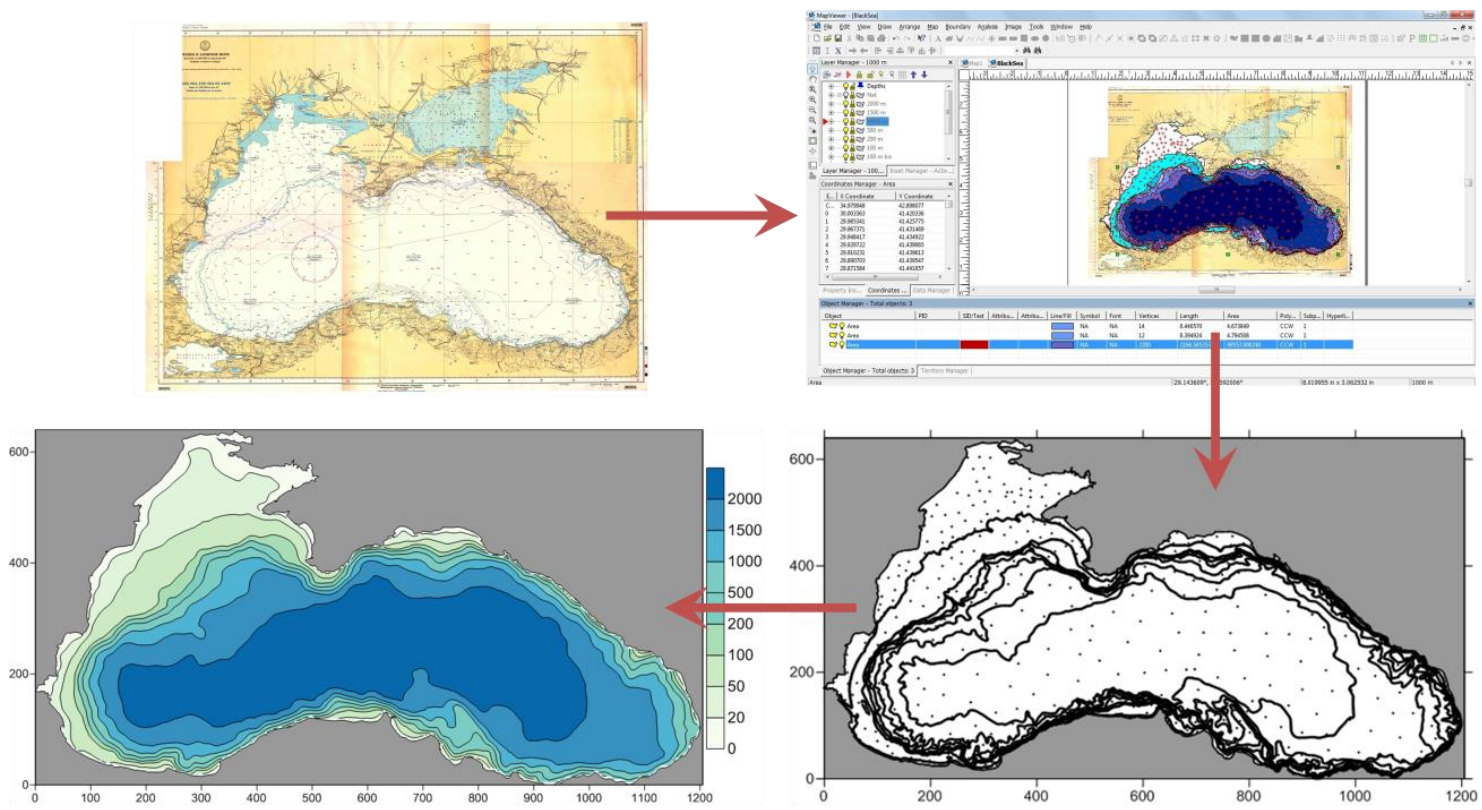

Figure 1. Schematic representation of the process of creating a rectangular matrix by means of digitizing a scanned map.

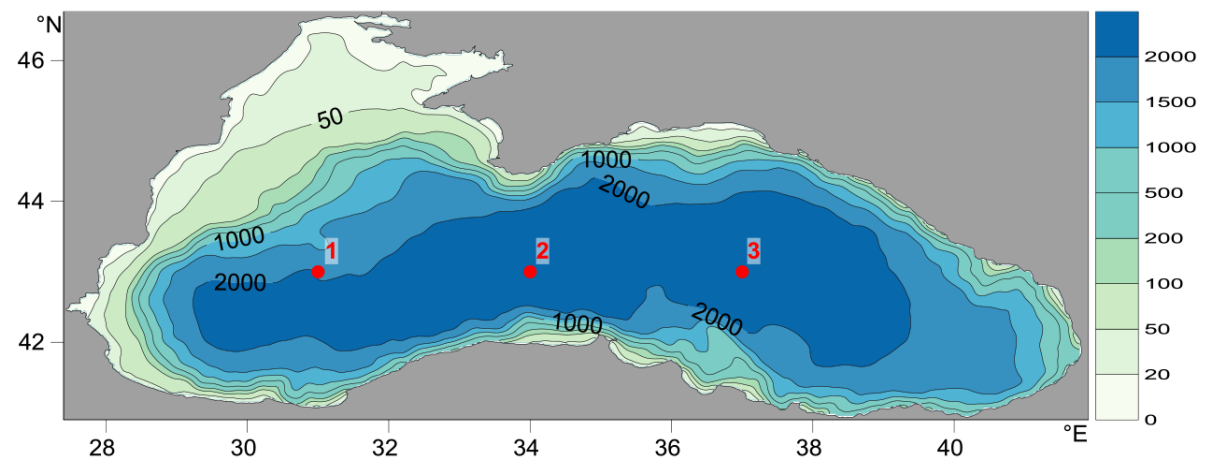

Figure 2. Bathymetry of the study area. Depths are in metres. Red dots indicate validation points.

no significant storminess change has been observed in the German Bight since 1876 (Schmidt and von Storch, 1993). On the other hand, a 40-year wave hindcast carried out for the Northern Hemisphere indicated a rise of significant wave height in the Northeast Atlantic (Wang and Swail, 2001), which was found to have a correlation with the NAO index. Similar results are reported in the proceedings of the European scientific group on Waves and Storms in the North Atlantic (The WASA group, 1998).

\section{Overview of wave regime studies of the Black Sea}

Various aspects of wind waves in the Black Sea have been widely studied by researchers from nearly all surrounding countries. These investigations were carried out in the most active way during the latest decades, but several case studies were made much earlier. Probably the first detailed scien- tific description of a storm event was by Ivashintsev (1855), attempting to analyse a devastating storm which occurred on 14 November 1854 in the proximity of Balaklava and Sevastopol - two harbours on the extreme southwest of the Crimean Peninsula. This gale was remarkable because nearly 30 English warships forming the Sevastopol siege during the Crimean War sank during this storm.

More or less fundamental research of the wave climate of the Black Sea started in the second half of the 20th century in the USSR with the development of the stochastic approach in wind wave studies. The theoretical background is developed in e.g. Putz (1952), Darlington (1954), Munk (1955), Goodknight and Russel (1963), Pierson and Moskowitz (1964), Glukhovskij (1966) and Davidan et al. (1978). The results of applied studies are summarized in several monographs and handbooks, such as Rzheplinskiy (1969) and Simonov and Altman (1991). 

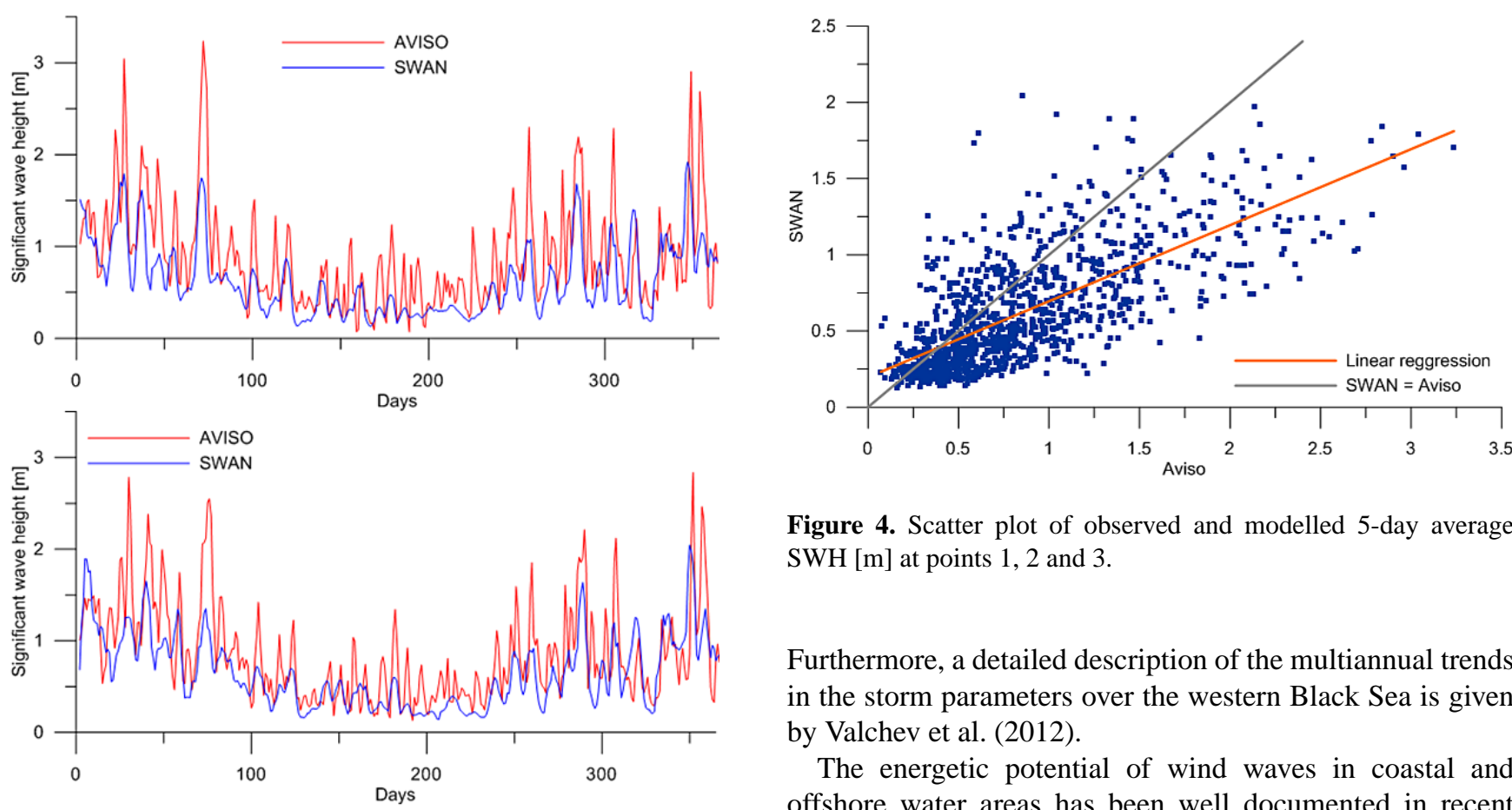

Figure 4. Scatter plot of observed and modelled 5-day average SWH $[\mathrm{m}]$ at points 1,2 and 3 .

Furthermore, a detailed description of the multiannual trends in the storm parameters over the western Black Sea is given by Valchev et al. (2012).

The energetic potential of wind waves in coastal and offshore water areas has been well documented in recent decades (e.g. Clément et al., 2002; Cornett, 2008; Falcão, 2010). Regarding the Black Sea, the problem of predicting and assessing the energetic potential of waves in various areas of the basin is discussed in the works of e.g. Rusu (2009), Akpinar and Kömürcü (2012) and Galabov (2013).

The present paper highlights some results of a modelling study of wind wave parameters and their variability in the Black Sea during more than 60 years based on the NCEP/NCAR reanalysis data (Kalnay et al., 1996), which has not previously been applied as forcing for wave simulations covering the entire sea. The goal of this study was to assess modern climatic parameters of wind waves in the Black Sea and to determine their spatial, annual and seasonal variability.

SWH $[\mathrm{m}]$ at point 1 (top), 2 (middle) and 3 (bottom).

Nowadays such research is continued by the Ukrainian scientific community. Studies of Komarovskaya et al. (2007), Efimov and Komarovskaya (2009) and Polonsky et al. (2011) are examples of investigations in extreme and climatic parameters of the whole sea. Another traditional research field is coastal studies, e.g. in bays and straits, such as Ivanov et al. (2009) and Alekseev et al. (2013).

Another region frequently studied for local cases is the Danube delta and the adjacent Romanian coast. The impact of wave-induced currents on the coastal transformation is discussed by Dan et al. (2009). A numerical study of interaction between currents generated by the Danube outflow and wind waves is described by E. Rusu (2010); variability of wave parameters and their statistical distribution properties are regarded as a result of wave impact. A demonstration of oil spilling forecast during offshore accidents through numerical modelling in this region can be found in L. Rusu (2010).

\section{Study area, data and methods}

\subsection{Study area}

The domain of the presented study is the entire Black Sea. The Black Sea is a quasi-enclosed basin of the World Ocean located between 41 and $46^{\circ} \mathrm{N}$ and 27 and $42^{\circ} \mathrm{E}$. It is connected to the Mediterranean Sea through the Sea of Marmara and the Bosporus and Dardanelles straits in its southwestern part and to the Sea of Azov through the Kerch Strait in the opposite northeastern one. Another feature of the Black Sea is its steep continental slope and very narrow continental shelf - except of the northwestern and western areas. Thus, the greater part of the sea is a basin with a relatively flat bottom relief and depths exceeding $2000 \mathrm{~m}$. Furthermore, a great part of the Black Sea's coast is surrounded by mountains - the Balkans, the Pontic Mountains, the Caucasus and 

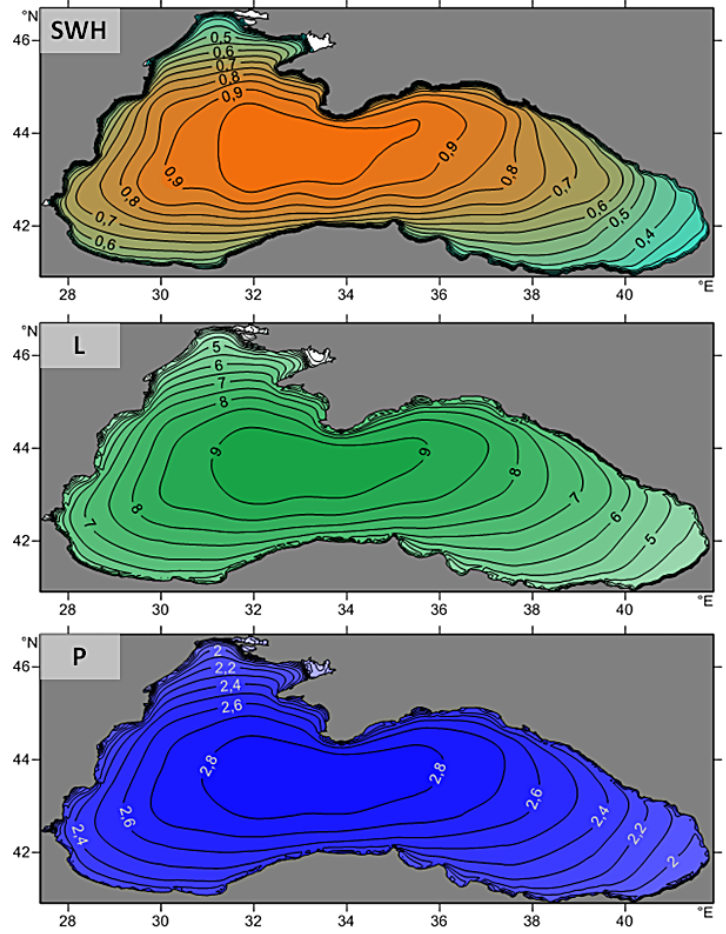

Figure 5. Maps of calculated average significant wave height [m], wave length $[\mathrm{m}]$ and period $[\mathrm{s}]$ in winter.
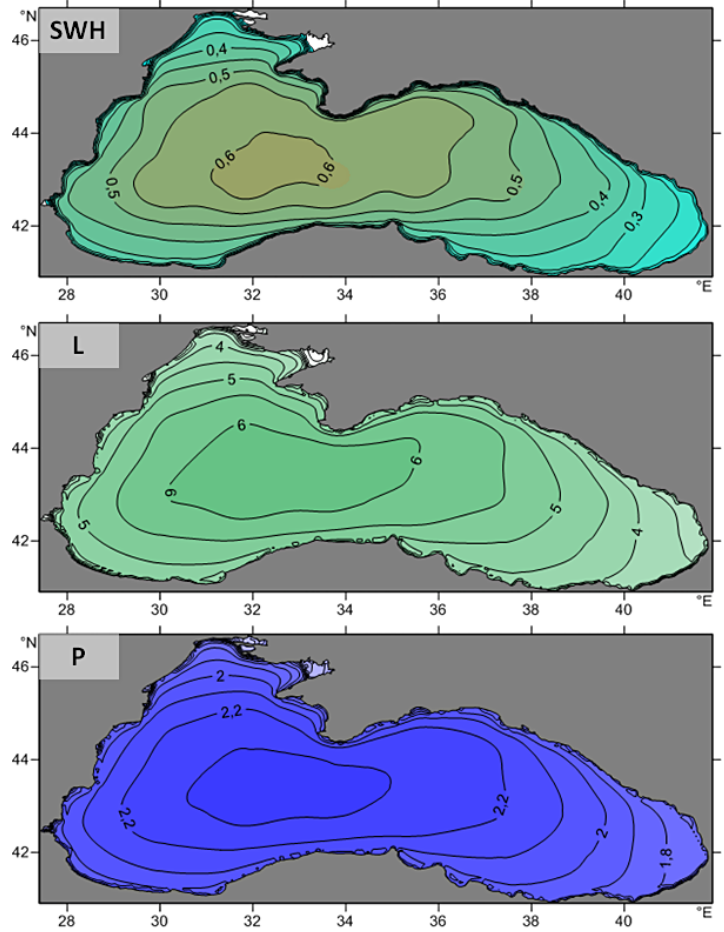

Figure 6. Maps of calculated average significant wave height [m], wave length $[\mathrm{m}]$ and period $[\mathrm{s}]$ in spring.
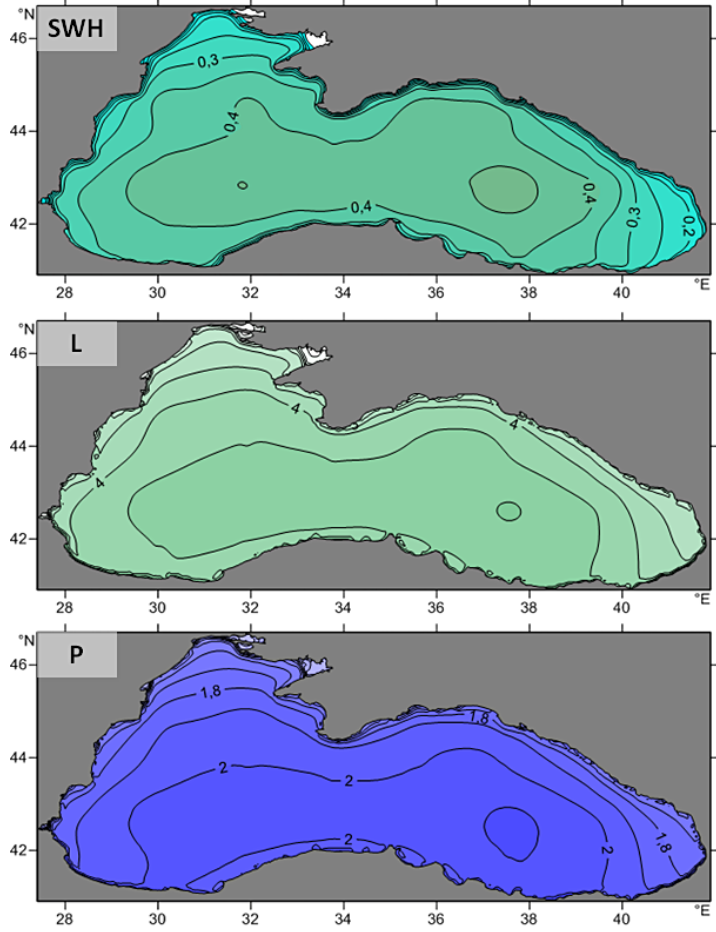

Figure 7. Maps of calculated average significant wave height [m], wave length $[\mathrm{m}]$ and period $[\mathrm{s}]$ in summer.
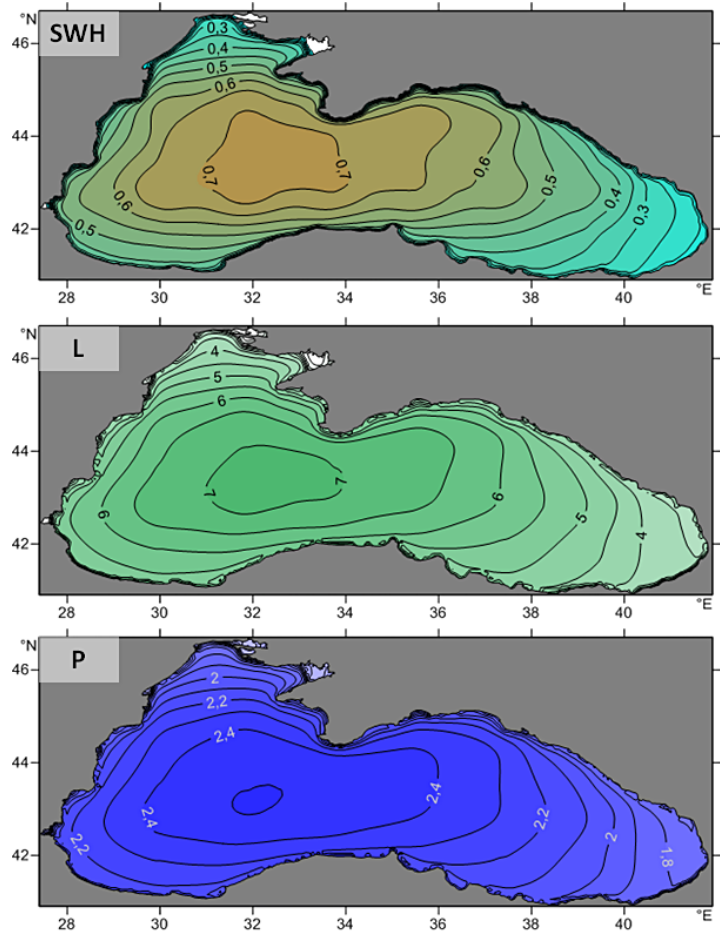

Figure 8. Maps of calculated average significant wave height [m], wave length [m] and period [s] in autumn. 
the Crimean mountains. This feature generates specific wind patterns in the coastal areas of the sea. An expanded description of the whole Black Sea system can be found in Özsoy and Ünlüata (1997) and Kostianoy and Kosarev (2008).

The general atmospheric circulation in the region is influenced by the configuration of the Azores and Siberian high-pressure areas and the Asian low-pressure area. Thus, in winter northeastern winds with speeds of $7-8 \mathrm{~m} \mathrm{~s}^{-1}$ prevail. Eastern winds with speeds of $5-7 \mathrm{~m} \mathrm{~s}^{-1}$ are predominant only in the southeastern areas of the sea. On the other hand, northwestern winds prevail in summer with typical speeds of 2-5 m s${ }^{-1}$ in coastal areas and 3-5 $\mathrm{m} \mathrm{s}^{-1}$ offshore. Wind speeds decrease in general from west to east (Dobrovolskij and Zalogin, 1982).

Besides this, local (mesoscale) winds, such as sea breezes, mountain-valley circulation, slope winds, foehns and bora have a remarkable impact on the atmospheric circulation pattern in the coastal areas of the Black Sea. The speed of breezes varies between $1-3 \mathrm{~m} \mathrm{~s}^{-1}$ for onshore and $3-5 \mathrm{~m} \mathrm{~s}^{-1}$ for offshore ones. Bora events are much more expressive with wind speeds reaching $25-30 \mathrm{~m} \mathrm{~s}^{-1}$ on the coast (Kostianoy and Kosarev, 2008).

\subsection{Data}

The initial data used in this study may be divided into two general groups: data on the bathymetry and coasts of the Black Sea and wind data in the studied domain.

An accurate bathymetry data set is needed to create a digital model of the bottom topography. This data set must be suitable for the chosen numerical grid resolution for further calculations. Already available bathymetry versions (e.g. the ETOPO database) do not represent the bottom relief of the Black Sea in an adequate way. For example, maximal depth values in some of these databases exceed $2400 \mathrm{~m}$, which is approximately $200 \mathrm{~m}$ deeper than the actual deepest point in the sea. In order to create a reliable data set a hydrographic chart of the Black Sea issued by the Main Naval and Oceanographic Administration of the Russian Ministry of Defence in 1996 was used. The scale of this chart is $1: 2500000$. Isobaths corresponding to depths of 20,50,100, 200, 500, 1500 and $2000 \mathrm{~m}$ are plotted on the chart as well as 514 separate points with corresponding depth values.

The scanned image of this map was processed by means of the Golden Software MapViewer package. As a result, a database containing geographic coordinates of points and corresponding depth values was created. Afterwards geographic coordinates of all collected points were transformed to Cartesian ones and the irregularly distributed depth values were interpolated onto the nodes of a rectangular grid with a spatial resolution of $5 \times 5 \mathrm{~km}$. In order to avoid computational errors, small bays and capes having sizes roughly equal to the grid cell size were smoothed. Thus, a $129 \times 242$ cell matrix was created, which was used as the computational grid in the study (Fig. 1). The same database was previously applied for numerical hydrodynamic studies of the Black Sea (Arkhipkin et al., 2013).

Continuous wind forcing is needed for the calculation of wave parameters. For this purpose wind speed series (decomposed to $u$ and $v$ components) at $10 \mathrm{~m}$ height above the sea surface were selected from the NCEP/NCAR reanalysis. This reanalysis contains hindcast values of various meteorological parameters dating back to 1948 . The temporal resolution of this data set is $6 \mathrm{~h}$, while the spatial one is $1.875^{\circ}$ in the longitudinal direction and $1.9046^{\circ}$ in the latitudinal one. Data corresponding to the study domain were selected and interpolated on the computational grid. This reanalysis was chosen first of all due to its enormous temporal extent, which is significantly larger than most other analogues. A validation of wind data at $10 \mathrm{~m}$ height from the NCEP/NCAR reanalysis against measurements performed at standard meteorological stations and voluntarily on vessels in the investigated region is given in Kovzova (2006).

One should note that the use of low-resolution wind data as forcing may lead to blurred simulation results, especially in coastal areas. However, we believe that for the current goals (namely the assessment of wave parameters in the entire Black Sea) and with the current computational grid the usage of NCEP/NCAR is acceptable.

\subsection{Wave model}

Wave parameters were calculated by means of the thirdgeneration spectral wave model SWAN (Booij et al., 1999; Ris et al., 1999). This model is widely used all over the world for the calculation of wave parameters on various scales (e.g. Gorrell et al., 2011; Rusu et al., 2008; Van Ledden et al., 2009; Zijlema, 2010). It was also implemented in several Black Sea studies (e.g. Akpinar et al., 2012; Polonsky et al., 2011; Valchev et al., 2012). Version 40.81 of the model was applied. Calculations were carried out in third-generation mode. Exponential wave growth was described according to Komen et al. (1984). Bottom friction was parametrized by a constant JONSWAP spectrum (Hasselmann et al., 1973). Triad wave-wave interactions and diffraction were also considered. The computations were carried out continuously for every year. "Hot-files" containing wave parameters calculated during the last 3 days of a year were created to launch the computations for the next year. The directional resolution was $1^{\circ}$. In the frequency-space there were 21 logarithmically distributed divisions between 0.7 and $1 \mathrm{~Hz}$. The time step of the computations was $30 \mathrm{~min}$. At every time step values of significant wave height, wave period, mean length and direction were calculated at the nodes of the computational grid. These parameters were stored in the model's output file every $3 \mathrm{~h}$.

In order to validate the calculations satellite altimetry data were used. The altimeter products were produced and distributed by Aviso (http://www.aviso.altimetry.fr/), as part of the Ssalto ground processing segment. These data consist of 
Table 1. General statistical parameters of calculated against observed SWH values.

\begin{tabular}{|c|c|c|c|c|}
\hline \multicolumn{2}{|l|}{ Point no. } & 1 & 2 & 3 \\
\hline \multicolumn{2}{|l|}{ Coordinates } & $43^{\circ} \mathrm{N}, 31^{\circ} \mathrm{E}$ & $43^{\circ} \mathrm{N}, 34^{\circ} \mathrm{E}$ & $43^{\circ} \mathrm{N}, 37^{\circ} \mathrm{E}$ \\
\hline \multicolumn{2}{|c|}{ Maximal observed 5-day average SWH } & 3.2363 & 2.8370 & 2.6223 \\
\hline \multicolumn{2}{|c|}{ Maximal calculated 5-day average SWH } & 1.9205 & 2.0455 & 1.5582 \\
\hline \multicolumn{2}{|c|}{ Average observed 5-day average SWH } & 0.8908 & 0.8569 & 0.8211 \\
\hline \multicolumn{2}{|c|}{ Average calculated 5-day average SWH } & 0.6368 & 0.6576 & 0.5745 \\
\hline \multicolumn{2}{|c|}{ Minimal observed 5-day average SWH } & 0.0708 & 0.1293 & 0.1389 \\
\hline \multicolumn{2}{|c|}{ Minimal calculated 5-day average SWH } & 0.1300 & 0.1427 & 0.1568 \\
\hline \multirow{4}{*}{$\begin{array}{l}\text { Deviation between } \\
\text { observed and } \\
\text { calculated 5-day } \\
\text { average SWH }\end{array}$} & Maximal & 1.6690 & 1.5245 & 1.5400 \\
\hline & Average & 0.3423 & 0.3144 & 0.3256 \\
\hline & Standard deviation & 0.3061 & 0.2817 & 0.3006 \\
\hline & Minimal & 0.0007 & 0.0039 & 0.0017 \\
\hline \multicolumn{2}{|c|}{ Correlation coefficient ( $95 \%$ confidence) } & 0.7258 & 0.7149 & 0.7022 \\
\hline
\end{tabular}

5-day averaged SWH values with a spatial resolution of $1^{\circ}$. Three offshore locations corresponding to nodes of the Aviso grid were selected for validation (Fig. 2). Simulated SWH values at these locations were averaged over the same time periods as the Aviso data. Data corresponding to the entire year 2010 were selected for the validation. Some numerical parameters of the comparison are presented in Table 1; plotted time series and scatters of averaged modelled and measured SWH values are shown in Figs. 3 and 4. The comparison demonstrates that modelled SWH is usually somewhat lower than observed SWH - the average deviation between these values varies between 0.31 and 0.34 at various points. The overall patterns of observed and modelled SWH are similar - the mean correlation coefficient between AVISO and SWAN data is of 0.71 . Nearly all individual storm peaks are also observed in both data sets. The mentioned deviations may be caused by the coarse resolution of the wind forcing and possible underestimations of reanalysed wind speed values. Moreover, the relief surrounding the Black Sea also has an impact on the offshore wind conditions, which can be not represented in the reanalysis in the most accurate way. Similar modelling features with low-resolution forcing as the input are discussed by Akpinar et al. (2012).

Other examples of SWAN validation against in situ measurements performed by various gauges including wave buoys, an Acoustic Doppler Current Profiler and radars installed in the region of Novorossijsk and Gelendzhik is given in studies of Myslenkov and Arkhipkin (2013) and Ivonin et al. (2013). According to these results, the correlation coefficients vary between 0.64 and 0.92 . The RMS error between measured and observed values is between 0.2 and $0.49 \mathrm{~m}$.

\section{Results and discussion}

\subsection{Spatiotemporal patterns of wave parameters distribution}

In order to assess the features of the spatiotemporal distribution of wave parameters their average and maximal parameters corresponding to every season - winter (DecemberFebruary), spring (March-May), summer (June-August) and autumn (September-November) - were calculated.

Average wave parameters are at a maximum in winter. Thus, maximal values of average wave height corresponding to the period between December and February exceed $0.95 \mathrm{~m}$. Areas of most expressed storminess in terms of all average values correspond to the central part of the basin (Fig. 5). The same spatial pattern is also observed in the distribution of average wave parameters corresponding to spring (Fig. 6). However, their values are significantly lower. For instance, maximal average SWH does not exceed $0.65 \mathrm{~m}$, with maximal wave length $6.5 \mathrm{~m}$ and maximal wave period $2.4 \mathrm{~s}$. The most blurred wave fields correspond to summer (Fig. 7). In this season, average SWH exceeds $0.5 \mathrm{~m}$ only in a very compact area in the eastern Black Sea. The distribution of average wave parameters on the remaining surface of the Black Sea is much more uniform than in all other seasons. An intensification of wave processes is observed in autumn (Fig. 8). During the period between September and November the typical spatial pattern with highest waves corresponding to the central area of the sea is restored. In this season average wave heights exceed $0.7 \mathrm{~m}$, average wave length exceeds $7 \mathrm{~m}$ and average wave period exceeds $2.5 \mathrm{~s}$.

The temporal distribution of monthly average wave parameters is shown in Fig. 9. The seasonal trends are the same as these above. However, a result that can be derived from these data is the significant interannual variability of average wave parameters. For instance, the deviation between maximal and minimal average SWH in November is $0.67 \mathrm{~m}$. A 

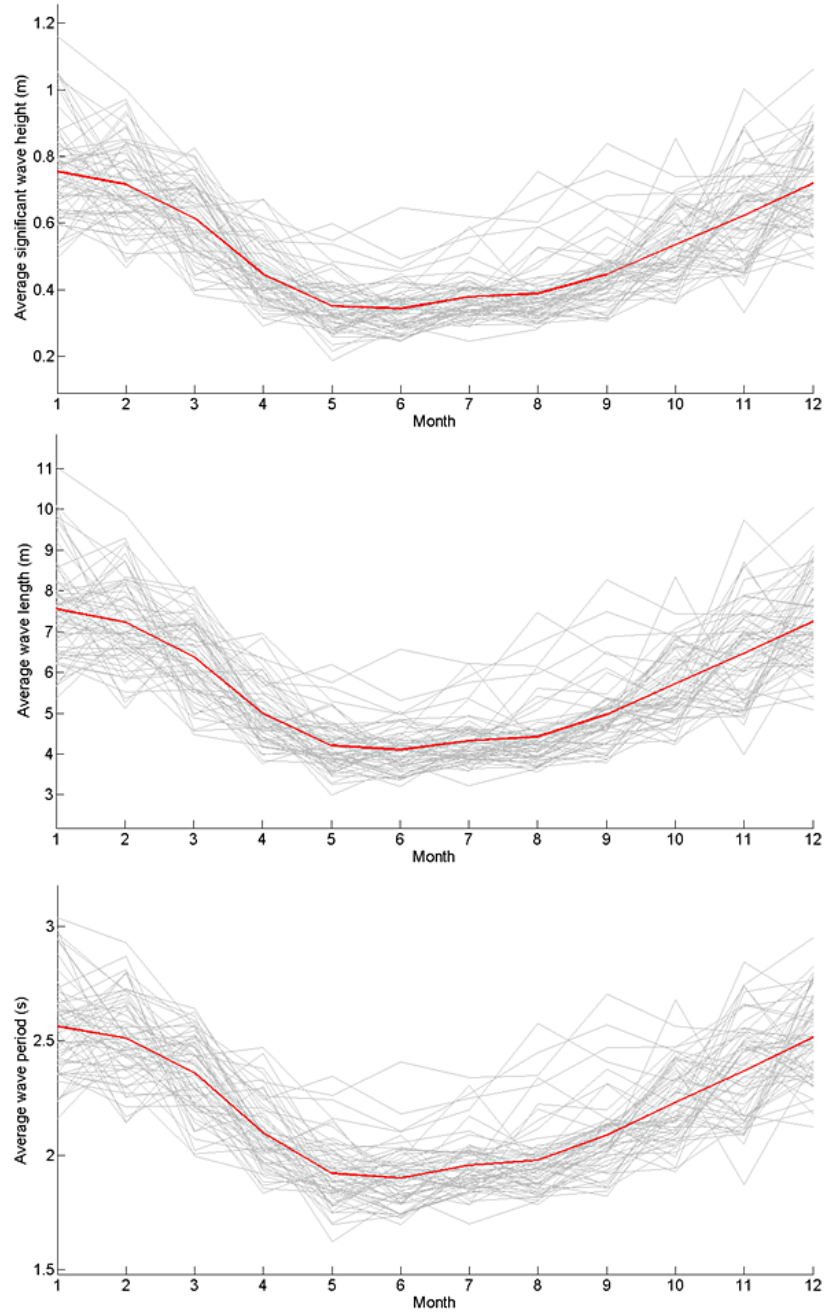

Figure 9. Monthly average values of significant wave height, wave length and period. Grey lines correspond to individual years, red lines show average values corresponding to the entire hindcast period.

slight decrease of this difference can be observed in summer (e.g. $0.4 \mathrm{~m}$ in June). The same patterns are typical for other wave parameters too.

Both spatial and temporal features of the distribution of maximal wave parameters are similar to those of average parameters. Thus, maximal SWH (over $6.5 \mathrm{~m}$ ) as well as wave lengths (over $55 \mathrm{~m}$ ) and periods (over $7 \mathrm{~s}$ ) correspond to winter and autumn (Figs. 10 and 13). Also, areas with largest waves in winter correspond to the southwestern region of the Black Sea, whereas these areas in autumn correspond to the northeastern region. In spring (Fig. 11) and summer (Fig. 12) wind waves are not as intense as during other seasons - maximal SWH does not exceed 6 and $4.5 \mathrm{~m}$, respectively. The most stormy area moves to the central parts of the sea and to the southern Crimean coast during these seasons.
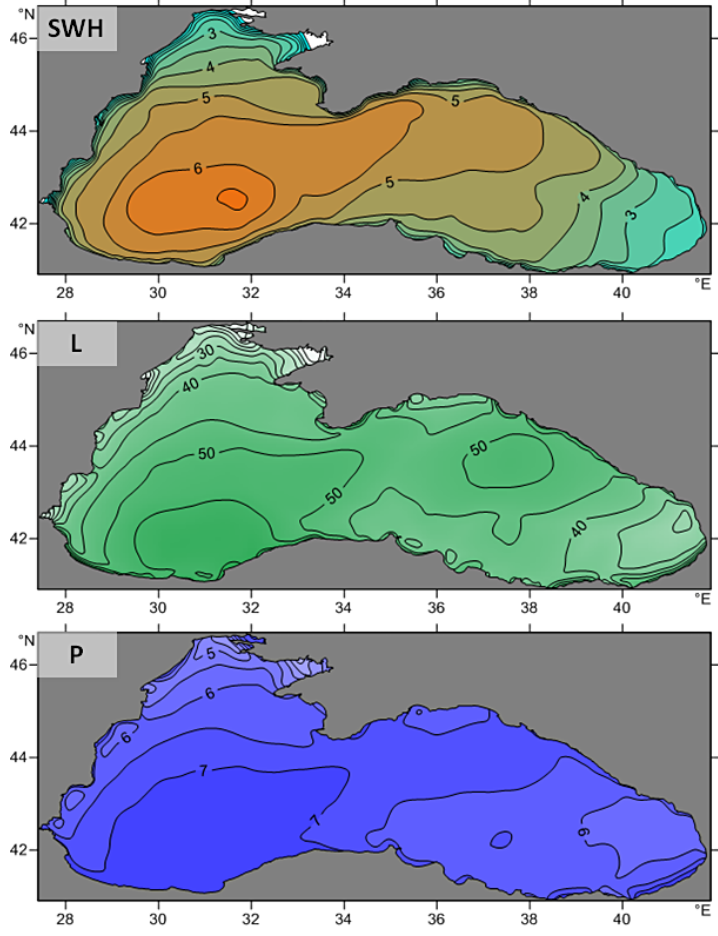

Figure 10. Maps of calculated significant wave height [m], wave length $[\mathrm{m}]$ and period $[\mathrm{s}]$ maxima in winter.
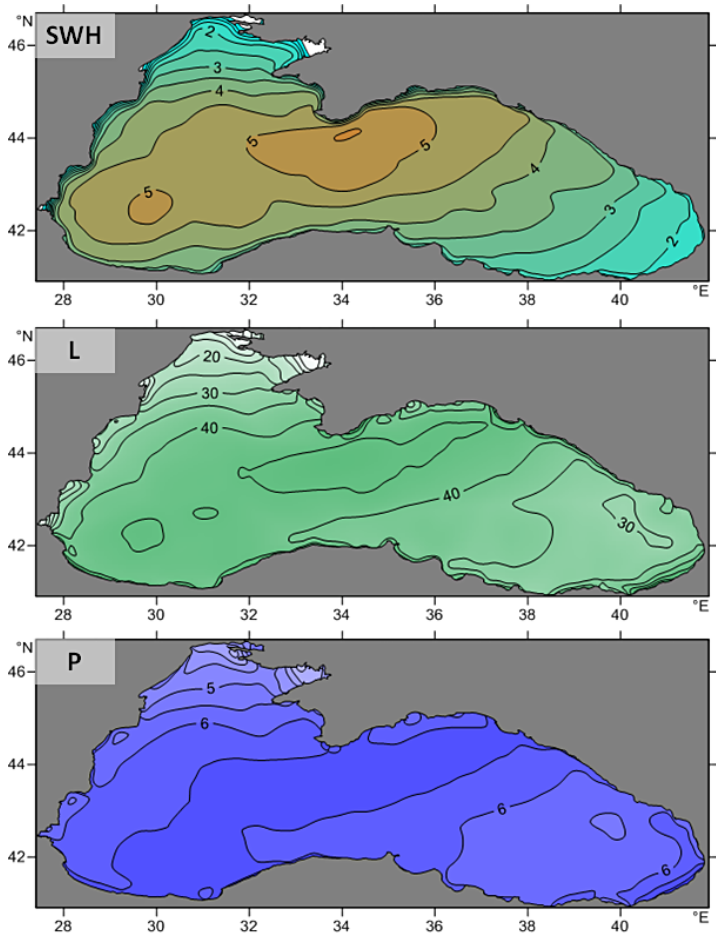

Figure 11. Maps of calculated significant wave height [m], wave length $[\mathrm{m}]$ and period $[\mathrm{s}]$ maxima in spring. 

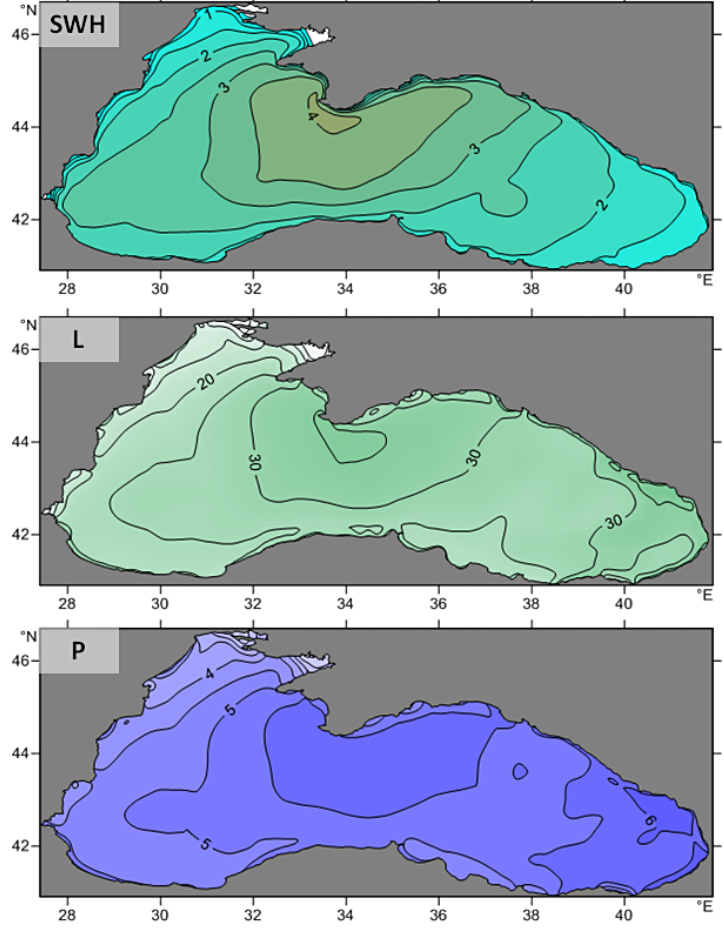

Figure 12. Maps of calculated significant wave height [m], wave length $[\mathrm{m}]$ and period [s] maxima in summer.
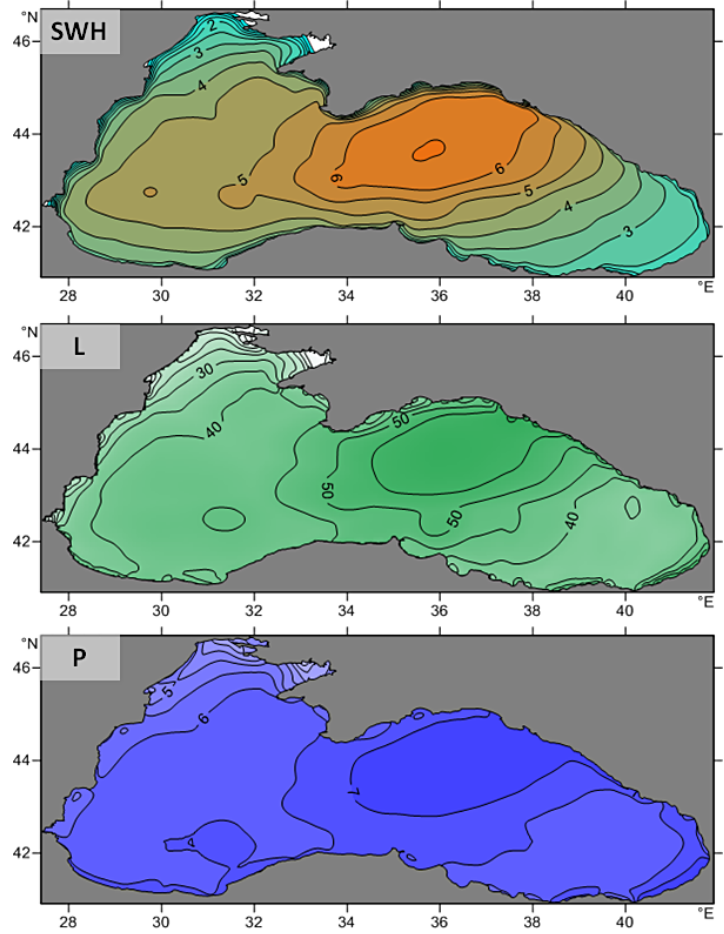

Figure 13. Maps of calculated significant wave height [m], wave length [m] and period [s] maxima in autumn.
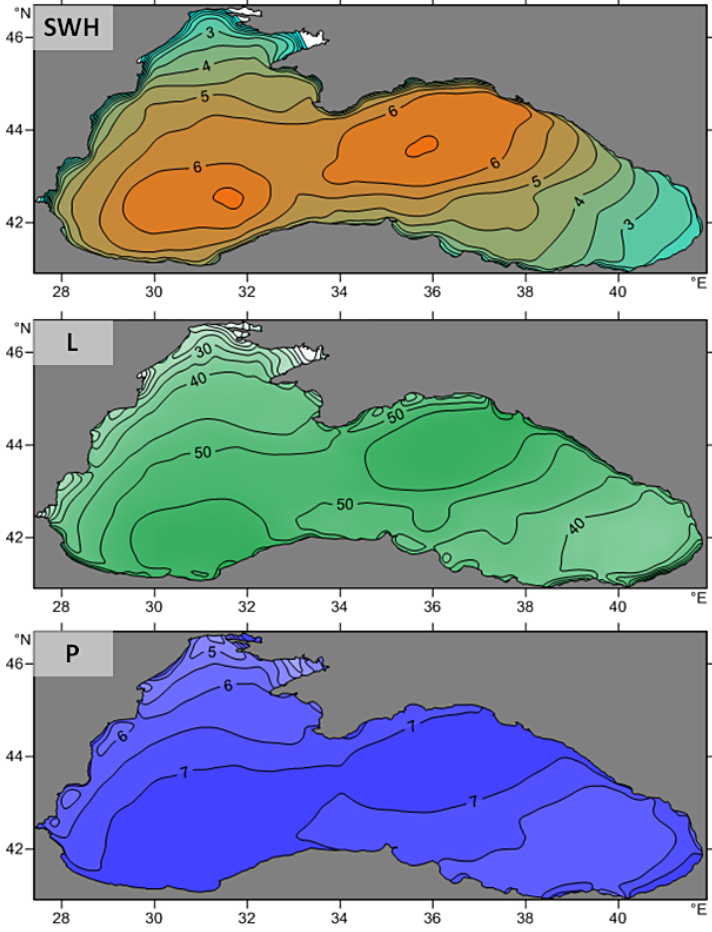

Figure 14. Maps of calculated significant wave height [m], wave length $[\mathrm{m}]$ and period $[\mathrm{s}]$ maxima.

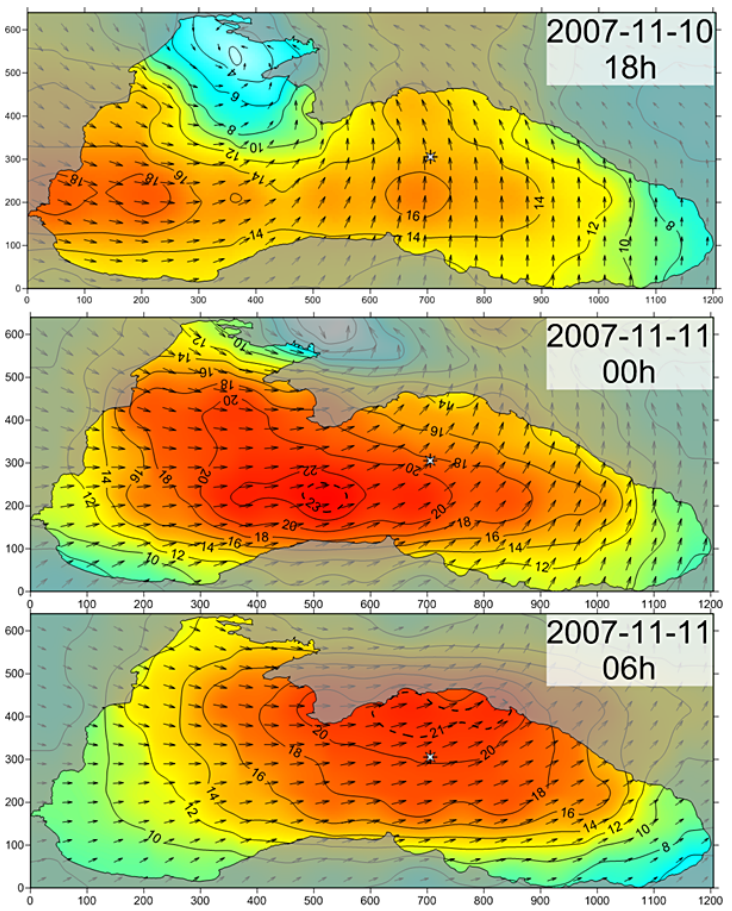

Figure 15. Wind speed $\left[\mathrm{m} \mathrm{s}^{-1}\right]$ and direction during the storm event in November 2007. The three locations of maximal calculated SWH during the storm are indicated by symbol. 

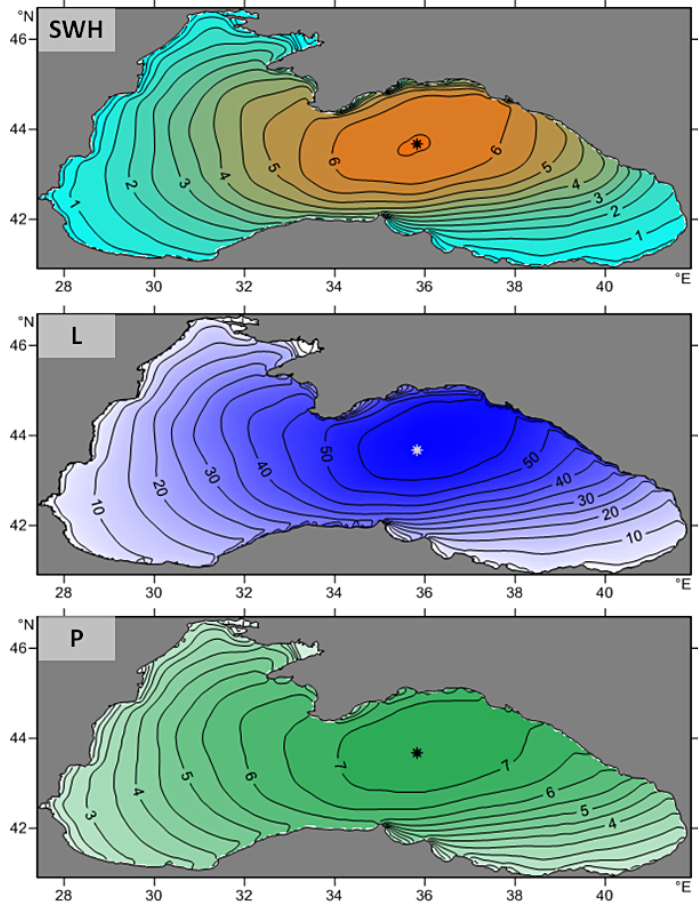

Figure 16. Maps of calculated significant wave height [m], wave length [m] and period [s] at $6 \mathrm{~h} \mathrm{UTC}, 11$ November 2007. The location of maximal calculated SWH during the storm is indicated by symbol.

The overall maximal wave parameter distribution is shown in Fig. 14. As already mentioned, two areas with most expressed storminess are determined in the Black Sea - one is south-western and the other is northeastern. Results of a similar wave hindcast study performed by means of the SWAN model, but forced by the JRA reanalysis for the period between 1979 and 2008, are presented in Polonsky et al. (2011). According to those results, there is also an area spreading from east to west across the Black Sea with SWH exceeding $7.5 \mathrm{~m}$ (which is approx. $1 \mathrm{~m}$ higher than according to our data). At the same time, waves in the offshore southeastern area of the sea are even more expressed according to the cited study and their significant height can be over $12 \mathrm{~m}$. This statement contradicts both results of the present paper and studies of individual storm cases in the western Black Sea. Thus, as reported by Galabov and Kortcheva (2013) maximal SWH observed at the Shkorpilovtsi location during the "Bulgarian storm of the century" in February 1979 according to instrumental observations was of at least $5.8 \mathrm{~m}$. On the other hand a numerical simulation of this storm using the SWAN model and ERA-Interim reanalysis (Dee et al., 2011) mentioned in the same paper demonstrated maximal SWH values of $4 \mathrm{~m}$, which is close to our results.

The calmest areas of the sea are its southeastern and northwestern parts. The first one is not strongly affected by the impact of cyclones, whereas the second one is the widest
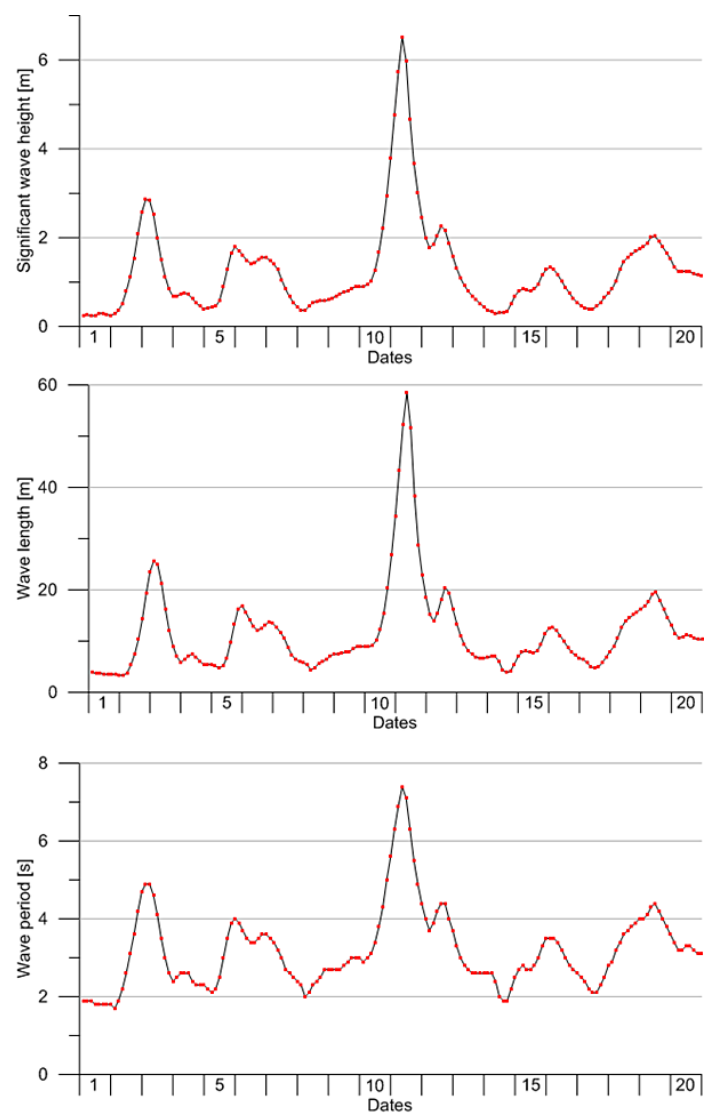

Figure 17. Time series of significant wave height, wave length and wave period at the point indicated on Fig. 16 in for the period between 1 and 20 November 2007.

shelf area in the Black Sea. Thus, wave growth is limited by the action of bottom friction here. In general, maximal wave heights decrease towards the coasts similarly to the average heights. However, the northeastern coast is periodically affected by storm waves higher than $6 \mathrm{~m}$.

One of such storms was observed on 11 November 2007. It caused serious damage to numerous vessels and coastal facilities in the Kerch Strait and adjacent regions. This event was reproduced by the presented hindcast as well. This storm was caused by the transition of a cyclone from the Balkans eastwards, which resulted in prevailing western winds with speed values exceeding $20 \mathrm{~m} \mathrm{~s}^{-1}$ over the entire Black Sea (Fig. 15). Thus, the fetch length was comparable with the whole longitudinal extension of the basin (approx. $600 \mathrm{~km}$ ). Highest waves generated by such combination of wind forcing and fetch length were observed at 06:00 UTC at the point with coordinates $43.67^{\circ} \mathrm{N}, 35.82^{\circ} \mathrm{E}$. According to our calculations, their SWH was of $6.52 \mathrm{~m}$ with corresponding wave length $58.6 \mathrm{~m}$ and period $7.4 \mathrm{~s}$ (Figs. 16 and 17). The predominant wave directions during this storm event were ESE and SE (Fig. 18). This storm was the most significant one in the northeastern part of the Black Sea at least during the whole year 2007. Maximal SWH reached during it was approx. 


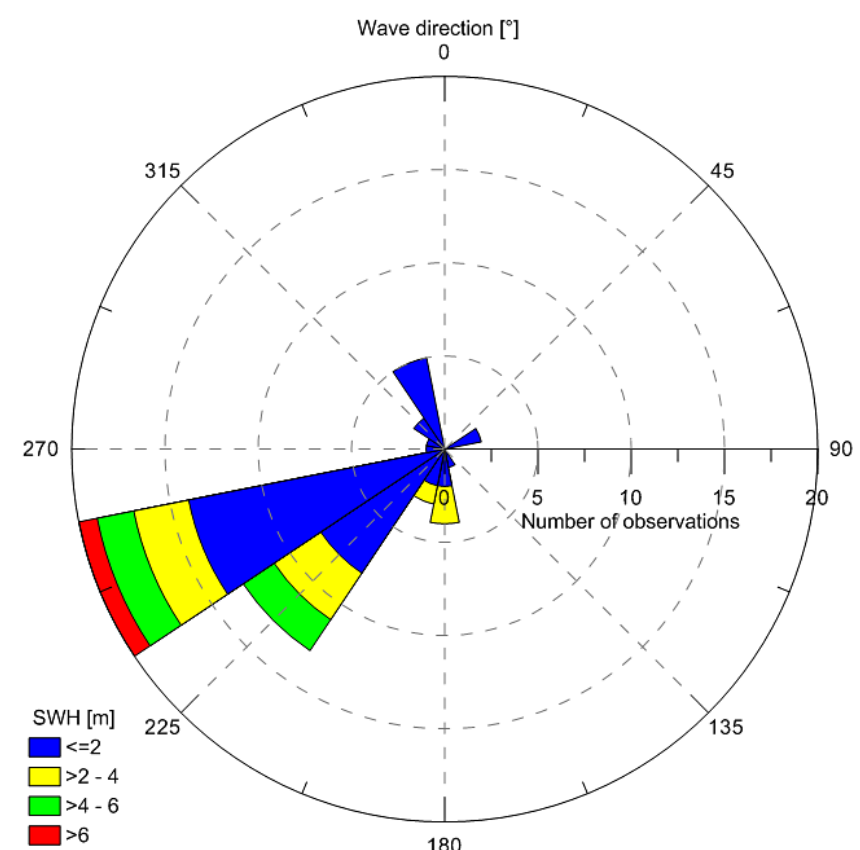

Figure 18. Wave rose at the point indicated on Fig. 16 for the period between 21 h UTC 7 November 2007 and 6 h UTC 14 November 2007.

$75 \%$ higher than during other storms, which occurred in January and February (Fig. 19). Regarding the wave direction, three predominant sectors can be determined, namely W, NE and SE. Meanwhile highest waves (with SWH exceeding $3 \mathrm{~m}$ ) are associated with the SE and ESE directions (Fig. 20).

The same storm event was previously studied by Bukhanovskij et al. (2009) also by means of the SWAN model, but on a coarser rectangular grid. Our results show satisfactory agreement with those published previously. Thus, absolute values of SWH are over $6 \mathrm{~m}$ in the northeastern area and below $3 \mathrm{~m}$ in the western and southeastern areas of the sea. The spatial patterns of SWH distribution are also nearly identical.

In order to define areas affected by the most severe storms the cumulative duration of waves with SWH higher than some certain threshold was analysed. Two threshold SWH values were selected: 2 and $4 \mathrm{~m}$. The spatial distribution of this parameter is shown on Fig. 21. In the case of waves with SWH exceeding $2 \mathrm{~m}$ the distribution of its total duration is characterized by a maximum in the central area of the Black Sea to the southwest of the Crimean peninsula. This area is influenced by nearly all cyclones passing over the Black Sea. On the other hand, waves with SWH over $4 \mathrm{~m}$ have a clear trend to be observed predominantly in the western Black Sea. Their total duration in the opposite northeastern area is only half of it.

The spatial distribution of the storminess intensity can be explained by the atmospheric circulation which is responsi-


Figure 19. Time series of significant wave height, wave length and wave period at the point indicated on Fig. 16 in 2007. Orange dashed lines indicate the period between 1 and 20 November.

ble for the wind pattern. There are two prevailing types of large-scale sea level pressure (SLP) fields causing storms over the Black Sea (Surkova et al., 2013). These types are revealed by clustering analysis ( $k$ means) from the set of SLP fields only for storm days with $\mathrm{SWH} \geq 4 \mathrm{~m}$. One SLP pattern is characterized by a cyclone over the Black Sea or nearby. The appearance of the cyclone is accompanied by a quick propagation of a trough from Scandinavia and the Baltic Sea. At the same time, high atmospheric pressure prevails to the west of the Black Sea region. Such a situation may lead to strong northwestern, western and southwestern winds (Fig. 22). The second pattern is characterized by the trough of atmospheric pressure spreading from the eastern Mediterranean towards the Black Sea and often forming a local cyclone over the Black Sea (Fig. 23). Its further movement to the north is blocked by the vast high-pressure centre over eastern Europe. Under the influence of the southern 


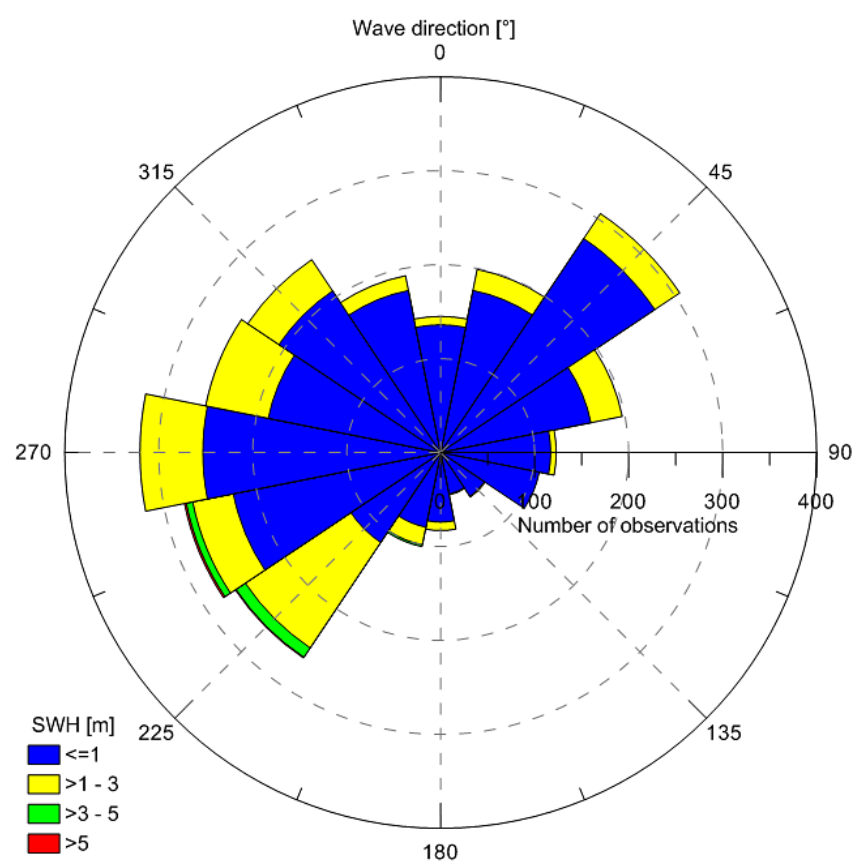

Figure 20. Wave rose at the point indicated on Fig. 16 in 2007.
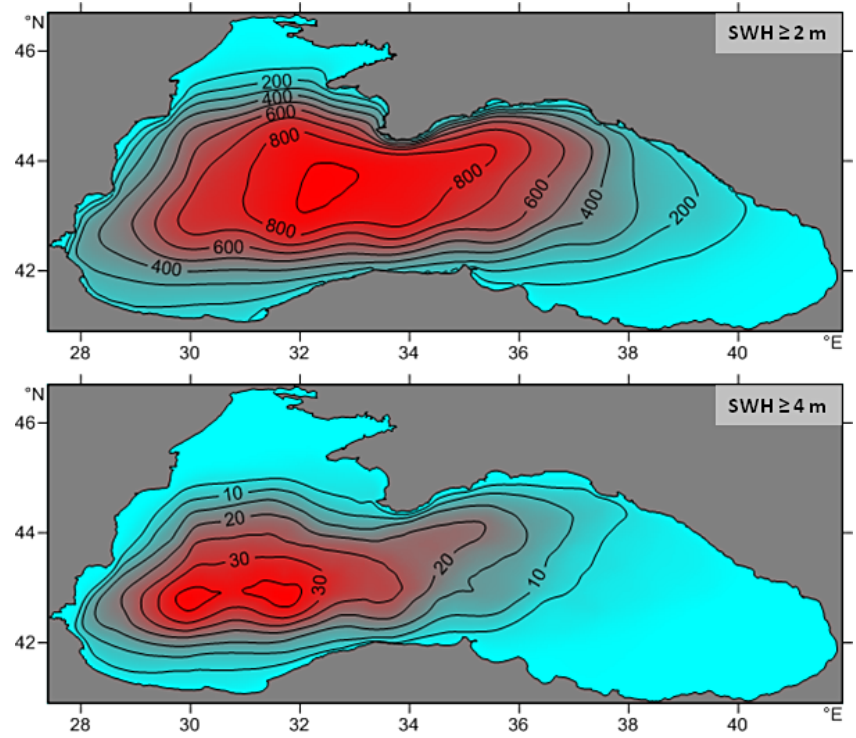

Figure 21. Total duration [days] of waves with SWH exceeding 2 and $4 \mathrm{~m}$ over the entire hindcast period.

trough, northeasterly, easterly and southeasterly winds are predominant over the Black Sea. When an independent Black Sea cyclone is generated at the periphery of the trough, the pattern of wind direction over the sea is more complicated and can be opposite in different parts of the sea.

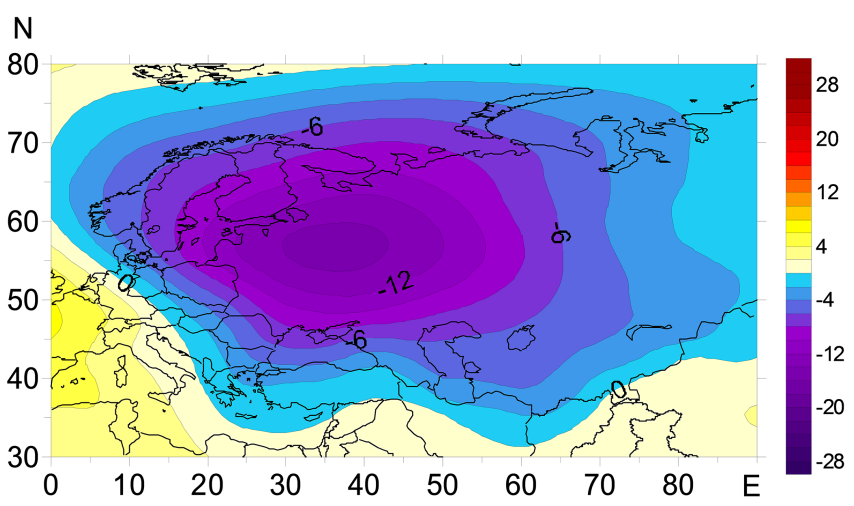

Figure 22. Composite of SLP anomaly corresponding to the first weather regime of storm days $[\mathrm{hPa}]$.

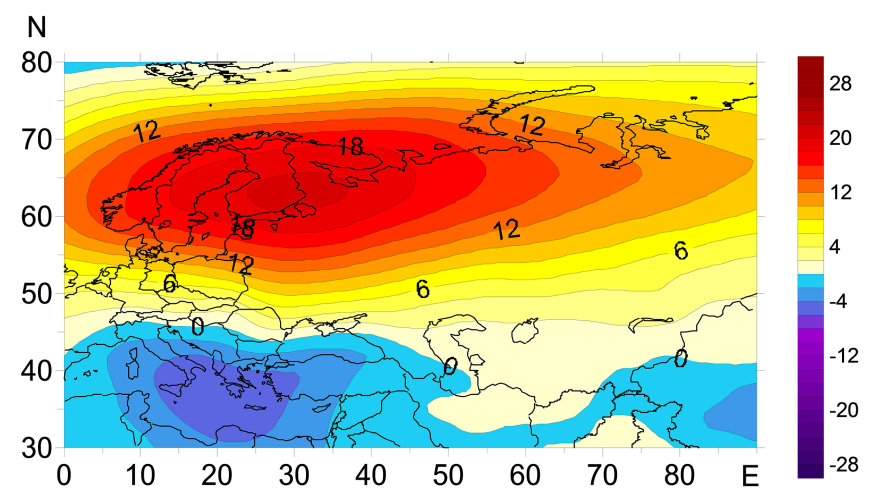

Figure 23. Composite of SLP anomaly corresponding to the second weather regime of storm days $[\mathrm{hPa}]$.

An estimation of wave heights possible once in 100 years was performed using the initial distribution method as described by Lopatoukhin and Boukhanovsky (2003) and based on the data set of calculated wave heights. According to this assessment, waves with SWH over $14 \mathrm{~m}$ may occur in an offshore area surrounding the Crimean peninsula from the southwest, south and southeast (Fig. 24). The spatial pattern of highest waves is similar to the distribution of average SWH, in winter and autumn in particular.

\subsection{Temporal variability of Black Sea storminess}

Some results concerning the average storminess parameters on the Black Sea were derived during this work. The presence of waves higher than $2 \mathrm{~m}$ during several output time steps was considered as a storm event. In total, more than 1500 such cases were observed. The average duration, area and track length of storms were identified. The area of a storm was calculated as the quantity of grid cells with SWH over $2 \mathrm{~m}$. In order to define the path length of a storm the distance between grid nodes with maximal SWH during two consequent time steps was calculated. Afterwards, these values were summarized for every individual storm event. The 


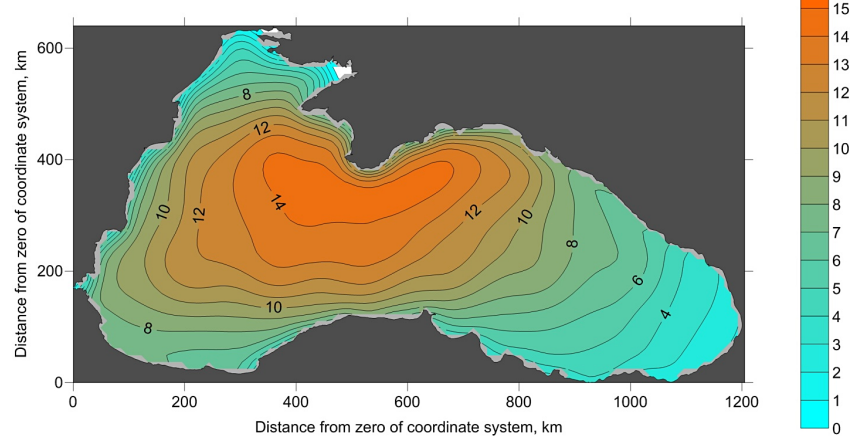

Figure 24. Map of predicted 100-year return period significant wave height $[\mathrm{m}]$.

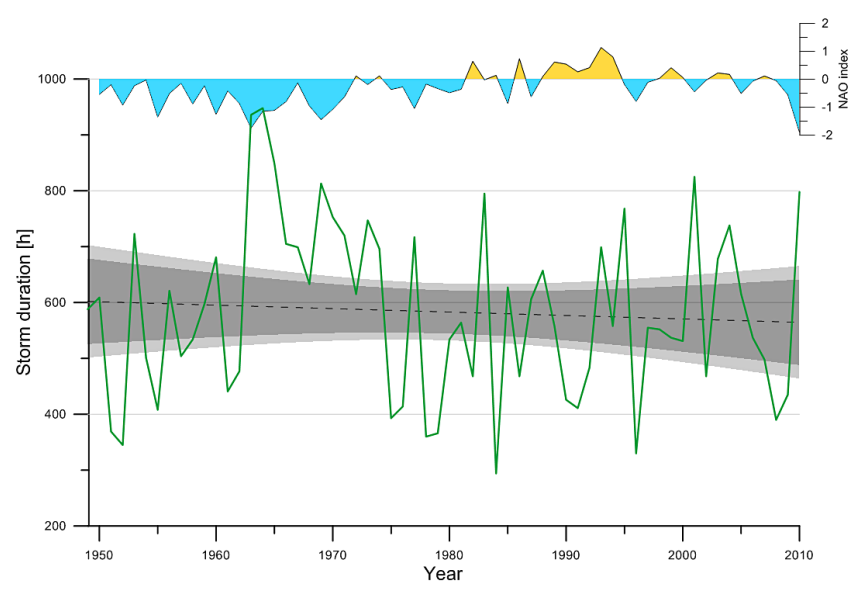

Figure 25. Interannual variability of the NAO index and total storm duration per year, its linear trend $\left(-0.62 \mathrm{~h} \mathrm{year}^{-1}\right)$, and $95 \%$ (dark grey) and $99 \%$ (light grey) confidence intervals.

storms have also been ranked depending on the maximal calculated wave height. The results of this analysis are presented in Table 2.

Storm cyclones over the Black Sea are connected with the global atmosphere circulation patterns. A connection with the NAO index (November-March) shows that periods with the lowest NAO index are accompanied by higher storminess (Figs. 25 and 26). Thus, the correlation coefficients between the NAO index and the storm duration and quantity are -0.35 and -0.25 , respectively. This may be interpreted as a decreasing influence of the Azores anticyclone's ridge over the Mediterranean and Black Sea allowing local cyclone intensification.

The interannual variability of total storm duration and of the number of storms over the period 1949-2010 was analysed. The linear trends of these series show a negligible decrease of both annual duration and quantity of storms $--0.62 \mathrm{~h} \mathrm{year}^{-1}$ and -0.02 storms year $^{-1}$. At the same time it is possible to determine a period of relative high storminess in the Black Sea. This period spans from the early 1960s until

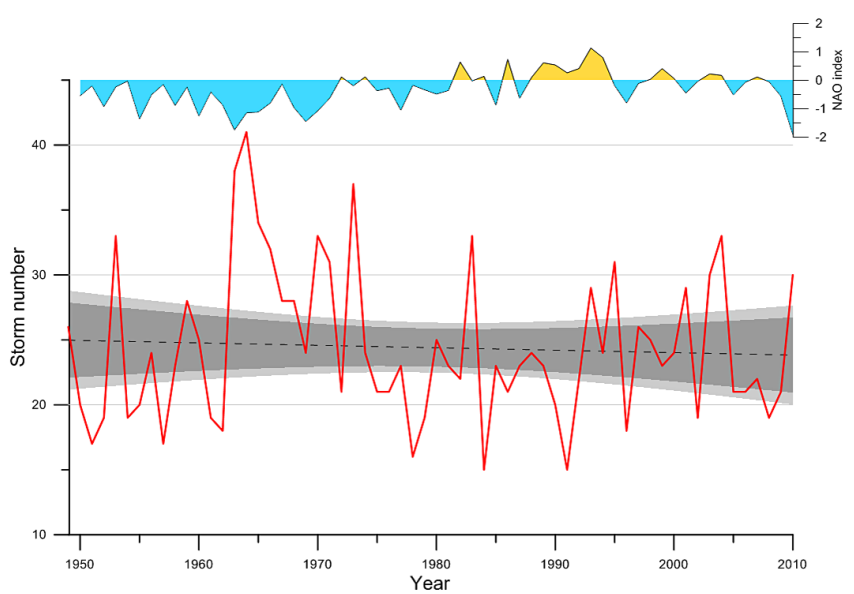

Figure 26. Interannual variability of the NAO index and storm events per year, its linear trend $\left(-0.02\right.$ storms year $\left.^{-1}\right)$, and $95 \%$ (dark grey) and $99 \%$ (light grey) confidence intervals.

Table 2. Quantity and average duration, area and path length of storms.

\begin{tabular}{lrrrr}
\hline $\begin{array}{l}\text { Maximal } \\
\text { SWH }[\mathrm{m}]\end{array}$ & Quantity & $\begin{array}{r}\text { Average } \\
\text { duration }[\mathrm{h}]\end{array}$ & $\begin{array}{r}\text { Average area } \\
{\left[\mathrm{km}^{2}\right]}\end{array}$ & $\begin{array}{r}\text { Average path } \\
\text { length }[\mathrm{km}]\end{array}$ \\
\hline $2 \leq \mathrm{h}<3$ & 1091 & 17.53 & 61135 & 218 \\
$3 \leq \mathrm{h}<4$ & 327 & 36.43 & 172246 & 506 \\
$4 \leq \mathrm{h}<5$ & 76 & 50.17 & 239343 & 597 \\
$\mathrm{~h} \geq 5$ & 19 & 68.68 & 259047 & 672 \\
\hline Total & 1513 & & & \\
Mean & & 23.90 & 96568 & 305 \\
\hline
\end{tabular}

approximately the middle of the 1970s. Other stormy years corresponding to negative NAO values are 1995, 2001, 2005 and 2010.

Such results generally match the data on storminess trends at the western coast of the Black Sea described by Valchev et al. (2012), where also a decreasing trend of storminess activity is stated. Moreover, the alternation of relative calm and stormy periods as well as the increase of storminess in approx. 1960-1975 is a typical feature not only for the Black Sea, but also for other European seas, e.g. the North and Baltic Seas as shown by Matulla et al. (2008).

Finally, the seasonal distribution of storm events was assessed. The maximal value of total average storm duration corresponds to winter months, January in particular. However, most prolonged heavy storms with wave heights exceeding $5 \mathrm{~m}$ do not meet this peculiarity and are observed in February. The calmest season of the year is summer. Cases of wave heights exceeding $4 \mathrm{~m}$ were found only in July, whereas storms with waves over $5 \mathrm{~m}$ high were not observed from April to September at all (Fig. 27). 


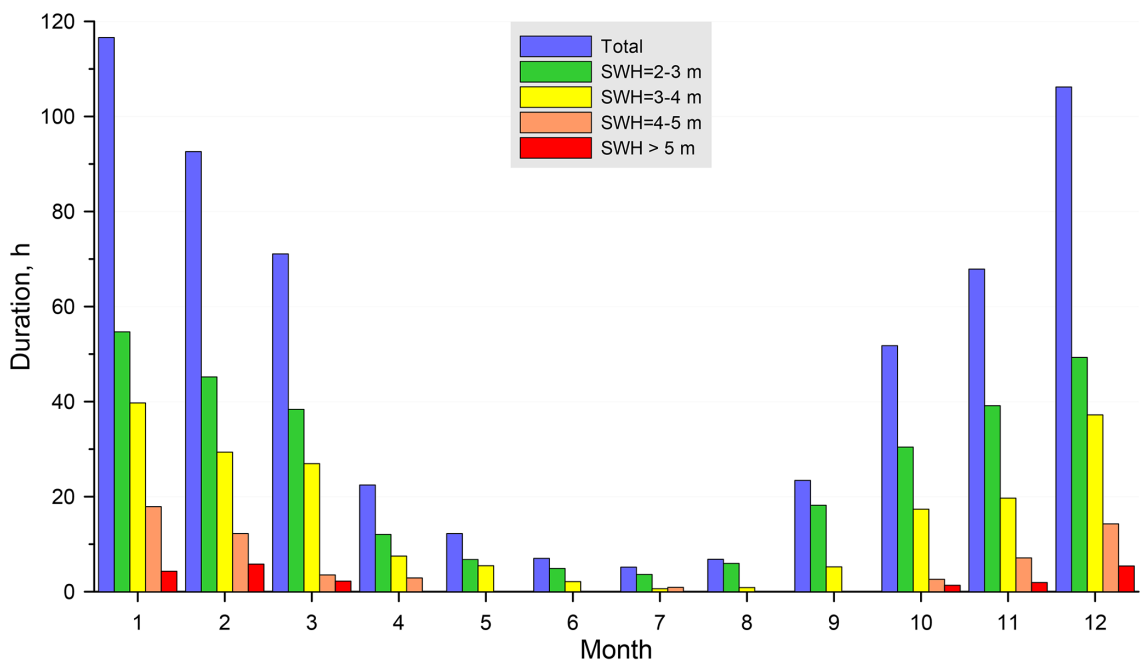

Figure 27. Average duration of storms per month (total and wave height dependent).

\section{Conclusions}

This paper shows the results of a hindcast study of wind waves on the Black Sea based on a continuous numerical calculation for the period between 1949 and 2010. The large time span of this period makes it possible to obtain reliable statistical and extreme parameters of wind waves, as well as to assess the evolution of the Black Sea's wave climate.

During this research average and extreme parameters of wind waves on the Black Sea were derived, which generally match with most recently published results. Additionally, an assessment of interannual and seasonal variability of storms on the Black Sea was carried out. A slight negative trend of both annual duration and quantity of storms was observed.

The results reported in this paper could be further applied in research with the use of other data sets and methods such as meteorological hindcasts having a finer temporal and/or spatial resolution, unstructured numerical grids and coupled models permitting the calculation of both waves and hydrodynamic parameters. The latter are expected to be especially useful for studies of the characteristics in coastal areas, bays and straits.

Acknowledgements. This study was carried out in the Natural Risk Assessment Laboratory (NRAL) of Lomonosov Moscow State University under contract no. G.34.31.0007.

The reported study was supported by the Supercomputing Centre of Lomonosov Moscow State University (Sadovnichy et al., 2013).

NCEP Reanalysis data provided by the NOAA/OAR/ESRL PSD, Boulder, Colorado, USA, from their Web site http://www.esrl.noaa. gov/psd/.

The authors gratefully acknowledge the careful attention and suggestions of two anonymous referees and the editor, which led to a significant improvement of the paper.
Edited by: A. Jansa

Reviewed by: two anonymous referees

\section{References}

Akpinar, A. and Kömürcü M. I.: Wave energy potential along the south-east coasts of the Black Sea, Energy, 42, 289-302, doi:10.1016/j.energy.2012.03.057, 2012.

Akpinar, A., van Vledder, G. Ph., Kömürcü M. I., and Özger, M.: Evaluation of the numerical wave model (SWAN) for wave simulation in the Black Sea, Cont. Shelf Res., 50-51, 80-99, doi:10.1016/j.csr.2012.09.012, 2012.

Alekseev, D. V., Ivanov, V. A., Ivancha, E. V., Fomin, V. V., and Cherkesov, L. V.: Estimation of the effect of protective piers on wind wave parameters in the Sevastopol Bay, Russian Meteorology and Hydrology, 38, 248-255, doi:10.3103/S1068373913040067, 2013.

Alexander, L. V., Tett, S. F. B., and Jonsson, T.: Recent observed changes in severe storms over the United Kingdom and Iceland, Geophys. Res. Lett., 32, L13704, doi:10.1029/2005GL022371, 2005.

Arkhipkin, V. S., Kosarev, A. N., Gippius, F. N., and Migali., D. I.: Seasonal variations of climatic fields of temperature, salinity and water circulation in the Black and Caspian seas, Moscow University Bulletin, Series 5: Geography, 33-44, 2013 (in Russian).

Booij, N., Ris, R. C., and Holthuijsen, L. H.: A third-generation wave model for coastal regions: 1 . Model description and validation, J. Geophys. Res., 104, 7649-7666, 1999.

Bukhanovskij, A. W., Lopatukhin, L. I., Chernisheva, E. S., and Kolesov, A. M.: The storm on the Black Sea on 11 November 2007 and statistics of extreme storms of the sea, Proceedings of the Russian Georgaphical Society, 141, 71-80, 2009 (in Russian).

Charles, E., Idier, D., Delecluse, P., Déqué, M., and Le Cozannet, G.: Climate change impact on waves in the Bay of Biscay, France, Ocean Dynamics, 62, 831-848, doi:10.1007/s10236012-0534-8, 2012a. 
Charles, E., Idier, D., Thiébot, J., Le Cozannet, G., Pedreros, R., Ardhuin, F., and Planton, S.: Present wave climate in the Bay of Biscay: spatiotemporal variability and trends from 1958 to 2001, J. Clim., 25, 2020-2039, doi:10.1175/JCLI-D-11-00086.1, 2012b.

Clément, A., McCullen, P., Falcão, A., Fiorentino, A., Gardner, F., Hammarlund, K., Lemonis, G., Lewis, T., Nielsen, K., Petroncini, S., Pontes, M.-T., Schild, P., Sjöström, B.-O., Sørensen, H. C., and Thorpe, T.: Wave energy in Europe: current status and perspectives, Renewable and Sustainable Energy Reviews, 6, 405-431, doi:10.1016/S1364-0321(02)00009-6, 2002.

Cornett, A. M.: A global wave energy resource assessment, Proceedings of the Eighteenth International Offshore and Polar Engineering Conference, 318-326, 2008.

Dan, S., Stive, M. J. F., Walstra, D.-J. R., and Panin, N.: Wave climate, coastal sediment budget and shoreline changes for the Danube Delta, Marine Geology, 262, 39-49, doi:10.1016/j.margeo.2009.03.003, 2009.

Darlington, C. R.: The distribution of wave heights and periods in ocean waves, Q. J. Roy. Meteor. Soc., 80, 619-626, 1954.

Davidan, I. N., Lopatukhin, L. I., and Rozhkov, V. A.: Wind waves as a probabilistic hydrodynamical process, Gidrometeoizdat, Leningrad, 1978 (in Russian).

Dee, D. P., Uppala, S. M., Simmons, A. J., Berrisford, P., Poli, P., Kobayashi, S., Andrae, U., Balmaseda, M. A., Balsamo, G., Bauer, P., Bechtold, P., Beljaars, A. C. M., van de Berg, L., Bidlot, J., Bormann, N., Delsol, C., Dragani, R., Fuentes, M., Geer, A. J., Haimberger, L., Healy, S. B., Hersbach, H., Hólm, E. V., Isaksen, L., Kållberg, P., Köhler, M., Matricardi, M., McNally, A. P., Monge-Sanz, B. M., Morcrette, J.-J., Park, B.-K., Peubey, C., de Rosnay, P., Tavolato, C., Thépaut, J.-N., and Vitart, F.: The ERA-Interim reanalysis: configuration and performance of the data assimilation system, Q. J. Roy. Meteor. Soc., 137, 553-597, doi:10.1002/qj.828, 2011.

Dobrovolskij, A. D. and Zalogin, B. S.: Seas of the USSR, Moscow State University publishers, Moscow, 1982 (in Russian).

Dodet, G., Bertin, X., and Taborda, R..: Wave climate variability in the North-East Atlantic Ocean over the last six decades, Ocean Modelling, 31, 120-131, doi:10.1016/j.ocemod.2009.10.010, 2010.

Dolan, R., Lins, H., and Hayden, B.: Mid-Atlantic Coastal Storms, J. Coastal Res., 4, 417-433, 1988.

Efimov, V. V. and Komarovskaya, O.I.: Atlas of extreme wind waves in the Black Sea, EKOSI-Gidrofizika, Sevastopol, 2009 (in Russian).

Falcão, A. F. O.: Wave energy utilization: A review of the technologies, Renewable and Sustainable Energy Reviews, 14, 899-918, doi:10.1016/j.rser.2009.11.003, 2010.

Galabov, V.: On the wave energy potential of the Bulgarian Black Sea coast, 831-838, doi:10.5593/SGEM2013/BC3/S15.003, 2013.

Galabov, V. and Kortcheva, A.: The influence of the meteorological forcing on the reconstructions of historical storms in the Black Sea, SGEM2013 Conference Proceedings, 855-862, doi:10.5593/SGEM2013/BC3/S15.006, 2013.

Glukhovskij, B. H.: Studies of marine wind waves, Hydrometeorological publishers, Leningrad, 1966 (in Russian).
Goodknight, R. C. and Russel, T. L.: Investigation of the statistics of wave heights, Journal of Waterways and Harbors Division, ASCE, 89, 29-55, 1963.

Gorrell, L., Raubenheimer, B., Steve Elgar, and Guza, R. T.: SWAN predictions of waves observed in shallow water onshore of complex bathymetry, Coastal Engineering, 58, 510-516, doi:10.1016/j.coastaleng.2011.01.013, 2011.

Hasselmann, K., Barnett, T. P., Bouws, E., Carlson, H., Cartwright, D. E., Enke, K., Ewing, J. A., Gienapp, H., Hasselmann, D. E., Kruseman, P., Meerburg, A., Müller, P., Olbers, D. J., Richter, K., Sell, W., and Walden., H.: Measurements of Wind-Wave Growth and Swell Decay during the Joint North Sea Wave Project (JONSWAP), Ergänzungsheft zur Deutschen Hydrographishen Zeitschrift, Reihe A, Nr. 12, 1973.

Ivanov, V. A., Fomin, V. V., Cherkesov, L. V., and Shul'ga, T. Ya.: Influence of the Kerch Strait on surge phenomena and currents induced by cyclonic disturbances in the Sea of Azov, Physical Oceanography, 19, 197-210, doi:10.1007/s11110-009-90519, 2009.

Ivashintsev, N.: A study of the storm occurred on the Black Sea the 2/14 November 1854, Marine collected articles, vol. XVII, 1-25, 1855 (in Russian).

Ivonin, D. V., Myslenkov, S. A., Chernyshov, P. V., Arkhipkin, V. S., Telegin, V. A., Kuklev, S. B., Chernyshova, A. Y., and Pnonmarev, A. I.: Monitoring system of wind waves in coastal area of the Black Sea using coastal radars, direct wave measurements and modeling: First results, Regional Environmental issues, 4, 172-182, 2013 (in Russian).

Kaas, E., Tian-Shi, L., and Schmith, T.: Statistical hindcast of wind climatology in the North Atlantic and northwestern European region, Clim. Res., 7, 97-110, 1996.

Kalnay, E., Kanamitsu, M., Kistler, R., Collins, W., Deaven, D., Gandin, L., Iredell, M., Saha, S., White, G., Woollen, J., Zhu, Y., Leetmaa, A., Reynolds, R., Chelliah, M., Ebisuzaki, W., Higgins, W., Janowiak, J., Mo, K. C., Ropelewski, C., Wang, J., Jenne, R., and Joseph, D.: The NCEP/NCAR 40-year Reanalysis Project, B. Am. Meteorol Soc, 77, 437-471, 1996.

Komarovskaya, O. I., Efimov, V. V., and Barabanov, V. S.: Calculation of wind fields corresponding to storm events at the Black Sea using a numeric regional atmosphere circulation model, Meteorology and Hydrology, 7, 74-80, 2007 (in Russian).

Komen, G. J., Hasselmann, K., and Hasselmann, K.: On the Existence of a Fully Developed Wind-Sea Spectrum, J. Phys. Oceanogr., 14, 1271-1285, 1984.

Kostianoy, A. G. and Kosarev, A. N.: The Black Sea Environment, Springer, Berlin Heidelberg, 2008.

Kovzova, M. F. (Ed.): Information on wind and wave regime of the Baltic, North, Black, Azov and Mediterranean Seas, Russian Maritime Register of Shipping, St. Petersburg, 2006 (in Russian).

Kushnir, Y., Cardone, V. J., Greenwood, J. G., and Cane, M. A.: The Recent Increase in North Atlantic Wave Heights, J. Clim., 10, 2107-2113, 1997.

Lionello, P. and Sanna, A.: Mediterranean wave climate variability and its links with NAO and Indian Monsoon, Clim. Dynam., 25, 611-623, doi:10.1007/s00382-005-0025-4, 2005.

Lopatoukhin, L. and Boukhanovsky, A.: Wind and Wave Climate Investigations, Related to Offshore Activity, The Tenth OMISAR Workshop on Ocean Models, 2003. 
Matulla, C., Schöner, W., Alexandersson, H., von Storch, H., and Wang, X. L.: European storminess: late nineteenth century to present, Clim. Dynam., 31, 125-130, doi:10.1007/s00382-0070333-y, 2008.

Munk, W. H.: Wind stress on water: An hypothesis, Q. J. Roy. Meteor. Soc., 81, 320-332, 1955.

Myslenkov, S. A. and Arkhipkin, V. S.: Analysis of wind waves in the Cemes Bay of the Black Sea using the SWAN model, Proceedings of Hydrometcentre of Russia, 350, 58-67, 2013 (in Russian).

Özsoy, E. and Ünlüata, Ü.: Oceanography of the Black Sea: a review of some recent results, Earth-Sci. Rev., 42, 231-272, 1997.

Peterson, E. W. and Hasse, L.: Did the Beaufort Scale or the Wind Climate Change?, J. Phys. Oceanogr., 17, 1071-1074, 1987.

Pierson Jr., W. and Moskowitz, L.: A proposed spectral form for fully developed wind seas based on the similarity theory of S.A. Kitaigorodskij, J. Geophys. Res., 69, 5181-5190, 1964.

Polonsky, A. B., Fomin, V. V., and Garmashov, A. V.: Characteristics of wind waves of the Black Sea, Reports of the National Academy of Sciences of Ukraine, 8, 108-112, 2011 (in Russian).

Ponce de Léon, S., Orfila, A., Gómez-Pujol, L., Renault, L., Vizoso, G., and Tintoré, J.: Assessment of wind models around the Balearic Islands for operational wave forecast, Appl. Ocean Res., 34, 1-9, doi:10.1016/j.apor.2011.09.001, 2012.

Putz, R. R.: Statistical distribution for ocean waves, Transactions, American Geophysical Union, 33, 685-692, 1952.

Ris, R. C., Holthuijsen, L. H., and Booij, N.: A third-generation wave model for coastal regions: 2. Verification, J. Geophys. Res, 104, 7667-7681, 1999.

Rusu, E.: Wave energy assessments in the Black Sea, J. Mar. Sci. Technol., 14, 359-372, doi:10.1007/s00773-009-0053-6, 2009.

Rusu, E.: Modelling of wave-current interactions at the moths of the Danube, J. Mar. Sci. Technol., 15, 143-159, doi:10.1007/s00773009-0078-x, 2010.

Rusu, E., Pilar. P, and Guedes Soares, C.: Evaluation of the wave conditions in Madeira Archipelago with spectral models, Ocean Engineering, 35, 1357-1371, doi:10.1016/j.oceaneng.2008.05.007, 2008.

Rusu, L.: Application of numerical models to evaluate oil spills propagation in the coastal environment of the Black Sea, J. Environ. Eng. Landsc., 18, 288-295, doi:10.3846/jeelm.2010.33, 2010.
Rzheplinkskij, G. V. (Ed.): Wind and Wave Atlas of the Black Sea, Gidrometeoizdat, Leningrad, 1969 (in Russian).

Sadovnichy, V., Tikhonravov, A., Voevodin, V., and Opanasenko, V.: "Lomonosov": Supercomputing at Moscow State University, Contemporary High Performance Computing: From Petascale toward Exascale, CRC Press, Boca Raton, USA, 283-307, 2013.

Schmidt, H. and von Storch, H.: German Bight storms analysed, Nature, 365, 791 pp., 1993.

Simonov A. and Altman, E. N. (Eds): Project "The USSR seas", Hydrometeorology and hydrochemistry of the USSR seas, 4, Black Sea: hydrometeorological conditions, Gidrometeoizdat, St. Petersburg, 1991 (in Russian).

Soares, C. G., Weisse, R., Carretero, J. C., and Alvarez, E.: A 40 years hindcast of wind, sea level and waves in European waters, Proceedings of OMAE 2002: 21st International Conference on Offshore Mechanics and Arctic Engineering, 2002.

Soomere, T.: Wind wave statistics in Tallinn Bay, Boreal environment research, 10, 103-118, 2005.

Sterl, A., Komen, G. J., and Cotton, P. D.: Fifteen years of global wave hindcasts using winds from the European Centre for Medium-Range Weather Forecasts reanalysis: Validating the reanalyzed winds and assessing the wave climate, J. Geophys. Res., 103, 5477-5492, 1998.

Surkova, G. V., Arkhipkin, V. S., and Kislov, A. V.: Atmospheric circulation and storm events in the Black Sea and Caspian Sea, Centr. Eur. J. Geosci., 5, 548-559, doi:10.2478/s13533-0120150-7, 2013.

The WASA Group: Changing Waves and Storms in the Northeast Atlantic?, B. Am. Meteorol. Soc., 79, 741-760, 1998.

Valchev, N. N., Trifonova, E. V., and Andreeva, N. K.: Past and recent trends in the western Black Sea storminess, Nat. Hazards Earth Syst. Sci., 12, 961-977, doi:10.5194/nhess-12-961-2012, 2012.

Van Ledden, M., Vaughn, G., Lansen, J., Wiersma, F., and Amsterdam, M.: Extreme wave event along the Guyana coastline in October 2005, Cont. Shelf Res., 29, 352-361, doi:10.1016/j.csr.2008.03.010, 2009.

Wang, X. L. and Swail, V. R.: Changes of Extreme Wave Heights in Northern Hemisphere Oceans and Related Atmospheric Circulation Regimes, J. Clim., 14, 2204-2221, 2001.

Zijlema, M.: Computation of wind-wave spectra in coastal waters with SWAN on unstructured grids, Coast. Eng., 57, 267-277, doi:10.1016/j.coastaleng.2009.10.011, 2010. 